\title{
Yeni Medyada Ürün Yerleştirmenin Ebeveynlerin Satın Alma Eğilimine Etkisi: Çocuk Videolarıyla İlgili Kırıkkale İlinde Bir Araştırma \\ (The Effect of Product Placement in New Media on Parental Purchasing Tendency: A Research on Children's Videos in Kirıkkale Province)
}

\author{
İbrahim BOZACI iDa Rabia VİLDAN İŞCAN iD $_{\mathrm{b}}$ İsmail GÖKDENİ iD $_{c}$ \\ a Kırıkkale Üniversitesi, Keskin Meslek Yüksekokulu, Kırıkkale, Türkiye, iborganizer@gmail.com

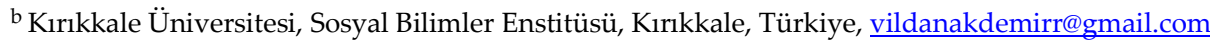 \\ ${ }^{c}$ Kırıkkale Üniversitesi, İktisadi ve İdari Bilimler Fakültesi, Kırıkale, Türkiye, isgokdeniz@gmail.com
}

\begin{tabular}{|c|c|}
\hline MAKALE BILGIISİ & ÖZET \\
\hline $\begin{array}{l}\text { Anahtar Kelimeler: } \\
\text { Yeni medya } \\
\text { Sosyal Medya } \\
\text { Ürün yerleştirme } \\
\text { Satın alma eğilimi }\end{array}$ & $\begin{array}{l}\text { Amaç - Ürün yerleştirme, tüketiciye pazarlama mesajlarının iletilmesinde kullanılan yöntemlerden } \\
\text { biridir. Sosyal ağlar başta olmak üzere günümüzde gelişen ve kullanımı yaygınlaşan yeni medya } \\
\text { araçları, ürün yerleştirmenin bu alanlarda da kullanılması sonucunu meydana getirmiştir. Bu } \\
\text { araştırmanın amacı, sosyal ağlardaki çocuklara yönelik videolarda ürün yerleştirmelerin, } \\
\text { ebeveynlerin videolardaki ürünleri satın alma eğilimine etkisini incelemektir. }\end{array}$ \\
\hline $\begin{array}{l}\text { Gönderme Tarihi } 1 \text { Haziran } 2019 \\
\text { Revizyon Tarihi } 20 \text { Temmuz 201 }\end{array}$ & $\begin{array}{l}\text { Yöntem - Yeni medyada ürün yerleştirmeyle ilgili çalışmaların genellikle internet tabanlı oyunlarla } \\
\text { ilgili olduğu görülmektedir. Çalışmanın amacı kapsamında Kırıkkale ilinde 1-8 yaş arası çocuğu } \\
\text { olan } 200 \text { ebeveynden birincil veriler kolayda örnekleme yöntemiyle toplanarak analiz edilmiştir. }\end{array}$ \\
\hline Kabul Tarihi 25 Temmuz 2019 & $\begin{array}{l}\text { Bulgular - Yapılan analiz sonucunda; videolardaki markalara yönelik tutumlar, videolardaki } \\
\text { ürünleri çocuğun satın alma talebi, reklam farkındalığı ve videolardaki ürünleri/markaları hatırlama } \\
\text { değişkenlerinin; videolardaki ürünleri satın alma eğilimini pozitif yönde etkilediği tespit edilmiştir. }\end{array}$ \\
\hline $\begin{array}{l}\text { Makale Kategorisi: } \\
\text { Araştırma Makalesi }\end{array}$ & $\begin{array}{l}\text { Tartışma - Araştırma bulguları, sosyal medyada çocuklara yönelik ürün yerleştirmenin, } \\
\text { ebeveynlerin satın alma eğilimlerini etkilemede önemli bir yöntem olabileceği fikrini } \\
\text { desteklemektedir. Bu noktada, çocuk videolarındaki markalara yönelik olumlu tutum oluşturmanın } \\
\text { işletmeler için yararlı olacağı söylenebilir. }\end{array}$ \\
\hline
\end{tabular}

\begin{tabular}{|c|c|}
\hline ARTICLE INFO & ABSTRACT \\
\hline $\begin{array}{l}\text { Keywords: } \\
\text { New media } \\
\text { Social Media } \\
\text { Product placement } \\
\text { Purchasing intention }\end{array}$ & $\begin{array}{l}\text { Purpose - Product placement is one of the methods used to deliver marketing messages to the } \\
\text { consumer. New media tools, especially social networks, which are developing and becoming } \\
\text { widespread today, have resulted in product placement in these areas as well. The aim of this study } \\
\text { is to investigate the effect of product placement on videos for children in social networks on parents' } \\
\text { tendency to purchase products in videos. }\end{array}$ \\
\hline $\begin{array}{l}\text { Received } 1 \text { June } 2019 \\
\text { Revised } 20 \text { July } 2019\end{array}$ & $\begin{array}{l}\text { Design/methodology/approach - Studies on product placement in new media are generally related } \\
\text { to internet-based games. Within the scope of the aim of the study, primary data were collected from } \\
200 \text { parents with children aged between 1-8 years in Kirkkale province by convenience sampling } \\
\text { method and analyzed. }\end{array}$ \\
\hline $\begin{array}{l}\text { Article Classification: } \\
\text { Research Article }\end{array}$ & $\begin{array}{l}\text { Findings - As a result of the analysis, it has been found that; the attitudes towards brands in the } \\
\text { videos, the request of the child to purchase the products in the videos, the awareness of advertising } \\
\text { and the recall of the products / brands in the videos, has a positive effect on the tendency to } \\
\text { purchase products in videos. }\end{array}$ \\
\hline & $\begin{array}{l}\text { Discussion - The findings of the study support the idea that placing products for children on social } \\
\text { media can be an important method for influencing parents' purchasing tendencies. At this point, it } \\
\text { can be said that creating a positive attitude towards brands in children's videos will be beneficial for } \\
\text { businesses. }\end{array}$ \\
\hline
\end{tabular}




\section{GİRIŞ}

Geleneksel medyanın parçalı hale gelmesi ve tüketicinin ticari mesajlardan kaçınma becerisinin artması, pazarlamacıların tüketicilere ulaşmak için yeni yöntemler geliştirmesine neden olmaktadır. Televizyon programlarına veya film öykülerine yerleştirilen ürün ve markalar bu yöntemlerden biridir (Gillespie vd., 2018). Ürün yerleştirme, bir bedel karşılığında medya araçlarında ilgi çekmeyecek düzeyde planlı olarak tüketiciyi ürün lehine olumlu etkilemek üzere markalı bir ürünün yer almasının sağlanması (Balasubramanian, 1994; Pechmann ve Shih, 1999) veya marka adı, ürün paketi, imzası veya diğer ticari mesajların hareketli resim, televizyon gösterisi veya müzik videosunda kullanması (Steortz, 1987) gibi şekillerde tanımlanmaktadır. Reklamların çoğu zaman tüketiciler tarafından olumlu karşılanmadığı göz önünde bulundurulduğunda (Williams vd., 2011) ürün yerleştirme reklamı eğlenceye çevirerek bu sorunun üstesinden gelmeye katkı sağlamaktadır (Argan vd., 2007).

Ürün yerleştirme günümüzde pek çok sektörde kullanılmaktadır. Film izlerken masanın üzerinde bir kurabiye markasına ait ürünleri, spor programı izlerken içecek markasına ait ürünleri görmek veya radyo programında pop yıldızıyla görüşmede işletmenin marka adını sık sık duymak mümkündür (McPherson, 2008). En büyük araba üreticilerinden biri olarak BMW'nin James Bond filmleri başta olmak üzere ürün yerleştirmeye yatırım yaptığı görülmektedir. Apple'ın ise yılda yüzden fazla ürün yerleştirmeden yararlandığı ileri sürülmektedir (Khan vd., 2016). Çocukların izlediği filmlerde de ürün yerleştirme ile karşılaşılmaktadır. Charlie ve Çikolata Fabrikası'nda; Nike, Süpermen Dönüyor'da; Budweise, Doritos, Aquafina, Küçük Tavuk'ta; Mickey Mouse, Tic Tac, Dummies, Madagaskar'da; Koka Kola, Krispy Kreme, Skubi Doo 2'de; Burger King, Fuji, Starbucks, Örümcek Adam 2'de; Burger King, eBay, Fritos, Nike, Köpek Balığı Hikayesi'nde; PlayStation, Elf'de; Barbie, Koka Kola, Nike, McDonald's, Monopoly, Kayıp Balık Nemo'da; eBay, Koka Kola, Dr. Pepper, McDonald's, Tropicana, Jurassic Park 3'te; Doritos, Nestle, Corona Cips, Shrek 2'de; Baskin Robbins; Fantastik Dörtlü'de; Kellogg's, Pepsei, Burger King gibi markalar kullanılmıştır (Hudson ve Elliott, 2013).

Pazarlama alanında ürün yerleştirmenin etkileri üzerine çok sayıda araştırma mevcuttur (Wenner, 2004; Mackay vd., 2009; Williams vd., 2011). Türkiye'de 2011 yılında en fazla izlenen filmler arasında yer alan Anadolu Kartalları'na yönelik gerçekleştirilen bir içerik analizi çalışmasında, markaların baş rol oyuncusu veya yardımcı oyuncu tarafından kullanıldığı ve logoların görünür ve algılanabilir şekilde yerleştirildiği tespit edilmiştir. Araştırmada; 7 marka için 131 saniye ürün yerleştirilmesi yapıldığı, en fazla ürün yerleştirmenin 40 saniye ile Sarar markasına ait olduğu, en az ise 7 saniye ile Renault ve Nokia markalarına ait olduğu görülmüştür. Ayrıca, Harley Davidson, Vestel, Fiat, Toyota markaları da bu filmde kullanılmıştır (Gökhan ve Eşidir, 2018).

İşletmeler, artan rekabet, değişen teknolojik şartlar ve tüketici iletişim kalıplarına bağlı olarak, güncel medya araçlarında ürün yerleştirme gerçekleştirmektedir. Yeni medya araçlarında (Instagram, Twitter, Facebook, YouYube, Bloglar vb.) izlenen videolarda ve öneri/paylaşımlarda tüketicilerin karşısına ürün yerleştirmeler çıkmaktadır. Birçok YouTuber kanallarında paylaşımlarının içerisinde markalar görünür olacak şekilde ürünlerin tanıtımını yapabilmektedir. Kısaca ürün yerleştirme ile reklamcılık anlayışı etkileşim, sosyalleşme, eğitim ve eğlence gibi unsurların daha çok ön planda yer aldığı bir şekle dönüşmektedir. İnternet teknolojisini kullanan akıllı telefon ve sosyal ağ kullanımının yaygınlaşması, bu kanallarda ürün yerleştirmenin önemini artırmaktadır. Bu bağlamda araştırmada, sosyal ağ videolarında kullanılan ürün yerleştirmelerin tüketiciler üzerindeki etkilerinin çocuk videoları bakımından incelenmesi amaçlanmaktadır. $\mathrm{Bu}$ kapsamda öncelikle ürün yerleştirme ve yeni medya araçlarında ürün yerleştirme ve tüketiciler üzerindeki etkileri ikincil veriler aracılığıyla incelenmektedir. Ardından, çocuk videolarındaki ürün yerleştirmelere yönelik algı ve tutumların ebeveynlerin bu videolardaki ürünleri satın alma eğilimine etkisiyle ilgili bir saha araştırması gerçekleştirilmektedir.

\section{2. ÜRÜN YERLEŞTIRMENIN TÜKETICIYYE ETKILLERI}

Ürün yerleştirmeyle ilgili araştırmalar genellikle televizyon filmleri başta olmak üzere geleneksel medyaya yönelik gerçekleştirilmiştir (Gupta vd., 2000, Karrh vd., 2001, Hackley vd., 2005; Matthes vd., 2007). Filmi izleyen insanlar, filmde kullanılan ürün ve markaları sosyal ve kişisel yaşamlarına yansıtabilmekte (DeLorme ve Reid, 1999), yerleştirilen ürünleri daha kolay hatırlayabilmekte (yardımlı veya yardımsız), ürünleri satın almak için daha kolay ikna olabilmekte, satın alabilmekte (Balasubramanian, 1994) ve özellikle 


\section{İ. Bozacı - R. V. İşçan - İ. Gökdeniz 11/3 (2019) 1482-1492}

anlatılan hikayenin yapısı ve duygusal tonuyla uyumlu olduğunda, ürün veya markalara yönelik daha olumlu tutumlara sahip olmaktadır (Gillespie vd., 2018).

Televizyon showlarında ürün yerleştirmenin satın alma davranışına etkisinin incelendiği bir araştırmada, sevilen bir karakterin ürünle etkileşimi olmasının veya ürünü tutundurmasının tüketicileri etkilediği görülmüştür (Patton, 2014). Tom Cruise'un, Hollywood filminde Hollywood sakızlarını çiğnemesi ve BMW'yi kullanmasıyla ilgili gerçekleştirilen bir araştırmada, tüketicilerin bu tür pazarlama iletişimlerine yönelik \% 70 oranında olumlu tutumlara sahip olduğu görülmüştür. Khan vd.'nin (2016) 600 tüketici ile gerçekleştirdiği araştırmada, ürün yerleştirme, ürün yerleştirmeye yönelik etik algılamalar ve program ünlüsünü tanımanın, tüketicinin satın alma eğilimini etkilediği görülmüştür (Khan vd., 2016).

Chan vd.'nin (2016) deneysel araştırmasında, göze çarpan (uzun süre kalması, ekranın merkezinde olması, tespitinin kolay olması) ürün yerleştirmelerinin daha kapsamlı işlemeye (markayı düşünme, dikkat etme, ekranda bulunma nedenini düşünme vb.) neden olduğunu ancak, bunun marka tutumlarıyla ters yönlü ilişkili olduğu görülmüştür. Dolayısıyla markaların çok göze çarpan şekilde konumlandırılmaması ilgili çalışmada önerilmektedir. Ayrıca ilgili araştırma bulguları, ürün yerleştirme özelliklerinin (göze çarpma vb.), pazarlama mesajının tüketici üzerindeki etkilerinin farklılaşmasına neden olabileceği fikrini göstermesi bakımından önemlidir.

\section{YENI MEDYADA ÜRÜN YERLEŞTİRME VE TÜKETICIYYE ETKILLERI}

Yeni medyanın ortaya çıkması ile ürün yerleştirmenin, markaların sözel veya görsel araçlarla, eğlenceli, eğitimsel veya bilgisel içeriklerde ticari amaçlarla kullanılması unsurlarından oluşan daha genel tanımlamaları yapılmaktadır (Russell ve Belch, 2005; La Ferle ve Edwards, 2006; Lee ve Faber, 2007). Bu noktada, sosyal ağ videoları, bilgisayar oyunları ve video oyunları gibi mesajların alındığı ortamlarda ürün yerleştirme yapılmaktadır (Schneider ve Cornwell, 2005; McPherson, 2008; Brennan, 2008; Mau vd., 2008). $\mathrm{Bu}$ ürün yerleştirme türleriyle ilgili insanların alg1 ve tutumları ve bunların tüketicilerin satın alma niyeti ve davranışlarını etkilemedeki gücü, pazarlama alanında güncel araştırma konularından biridir. Örneğin Lin ve Cho (2010), etkileşimli online ürün yerleştirme kullanımındaki artışın, ürünlerin sponsorlarına yönelik tutumları ve satın alma niyetlerini olumlu etkilediğini göstermiştir.

Yeni medyada ürün yerleştirme ve etkileri bakımından, internet ve bilgisayar tabanlı oyunlarla ilgili çok sayıda araştırma gerçekleştirilmiştir. İşletmeler, bilgisayar veya internet tabanlı oyunlar aracılığıyla, bunların bir parçası olarak marka veya ürünlerinin reklamını yapmaktadır (Waiguny vd., 2013). Bu oyunlar, insanlara markayla ilgili seçim özgürlügü (görüp görmemeyi belirleyebilme) sağlayabilmekte, incelikli ve zorlayıcı olmayan şekilde değerlendirilebilmekte ve oynayanların gerçek dünya tüketimiyle bağ kurmalarına neden olabilmektedir. Sosyal medyanın bir parçası olan sosyal oyunlar, MySpace, Facebook gibi sosyal ağ platformlarını kullanan, sosyal ağdaki arkadaşlarla birlikte, onlara karşı veya yan yana oynanabilen ve insanlar arasındaki sosyal bağları geliştirmeyi ve oyun içi ve dışında etkileşimleri artırmayı amaçlayan oyunlardır. Facebook'un günlük milyonlarca aktif kullanıcısı olan CastleVille oyununda; İsrailli çikolata markası Elite Taami Nutzz, oyuncuların arazilerinde markalı fıstıklar yetiştirmesine imkan veren bir ürün yerleştirme yapmıştır. Sosyal medya raporları, sosyal ağlardaki sanal ürün yerleştirmelerinin önemli bir gelir kaynağı olduğunu göstermektedir (Chen ve Deterding, 2013).

Bir ürün veya markanın reklamını yapmak amacıyla oluşturulan reklam oyunlarının (advergame); olumlu marka tutumlarını artırdığını gösteren araştırmalar vardır. Bunlar sayesinde duygu (eğlence, çekicilik vb.) transferi yapılabilmekte, yarışma ve hız gibi çağrışımlar tüketicide oluşturulabilmektedir. Diğer taraftan Waiguny vd.'nin (2013) araştırması, olumsuz içeriklerin (şiddet, çarpışma vb.) oyuna ve markaya (aşina olunmayan) yönelik tutumları olumsuz hale getirebildiğini göstermiştir.

Sosyal ağ sitelerindeki oyunların (SNS, Happy Network) etkilerin incelendiği nitel bir araştırmada, bu alandaki ürün yerleştirmelerin gerçek hayattaki tüketimi etkilediği sonucuna varılmıştır. Ayrıca tüketiciler, ürün yerleştirmeyi kesici veya engelleyici olmadığında uygun olarak kabul etmekte, aşırı ticarileşmedikçe kabul edilebilir olarak karşılamaktadır. Bunların yanında oyuncular, ürün yerleştirmeyi, bilinmeyen markaları farkına varmaktan ziyade, marka aşinalığını güçlendirici bir unsur veya gerçek hayattaki markaların sanal ortamla birleşmesi olarak görmekte ve markaların oyunla ilgili olması ve zekice yerleştirilmesi gerektiğini (hızlı tüketim ürünleri vb.) düşünmektedir (Chen ve Haley, 2014). 
Chaney vd. (2018) deneysel çalışmasında, yarış oyununda yerleştirilen tanınmış markaların büyüklüğünün (büyük, küçük) önemli olduğunu ancak, sıra (öncelik, yenilik) ve içine yerleşme düzeyinin (düşük, yüksek) etkili olmadığı sonucuna ulaşmıştır. Buna göre büyük ebatlı markalar daha kolay hatırlanmakta ve tanınmaktadır. Hang ve Auty (2009), oyunlarda ürün yerleştirmeye ilişkin gerçekleştirdiği deneysel araştırmasında; çocuklara oyuncuların giyeceği formaların markaları seçmelerini sağlamanın daha fazla tercihe neden olduğu sonucuna ulaşmıştır.

Tüm bunların yanında yeni medyada ürün yerleştirme, etik bakımdan da tartışılan bir konudur. Çünkü zararlı ürünlerin iletişim kanallarında yerleştirilmesinin, çocuk ve gençlerin zararlı ürün tüketimini artırdığını gösteren araştırmalar vardır (Brown ve Moodie, 2009). Örneğin Hudson ve Elliott'un (2013) araştırmasında çocukların ürün yerleştirilen bir programı izledikten sonra sağliksız ürünleri hatırlama düzeyinin yüksek olduğu görülmüştür. Özellikle sosyal medyada yapılan ürün yerleştirmelerde alkol ve tütün gibi ürünlerin kullanılması, konuyla ilgili önlemler alınması gerektiği fikrinin doğmasına neden olmuştur (Eagle ve Dahl, 2018). Cranwell vd.'nin (2015) Britanya'da gerçekleştirdiği araştırmada, alkol (\% $45)$, sigara (\% 22) ve elektronik sigara (\% 2) görsellerinin izlenen YouTube videolarının önemli bir kısmında yer aldığı tespit edilmiştir. Ayrıca alkol (\% 7), sigara (\% 4) ve elektronik sigara markaları (\% 1) da videolarda yer almaktadır. Absolut Tune ve Marlboro bunlardandır.

Yeni medyada ürün yerleştirmenin etik olarak incelenebileceği diğer bir boyut, savunmasız ve duygusal olan ve karar alma becerileri düşük olan küçük çocuklara yönelik ürün yerleştirmelerdir. Zira günümüzde akıllı telefonla meşgul olmaya başlama zamanının okul öncesi ve hatta çocuk henüz konuşmaya başlamadan dahi olabildiği yazarlarca gözlemlenmektedir. Bu şartlar altında, izlenen videolardaki ürün ve markalardan etkilenen çocuklar, bunları doğal olarak bilinçli bir değerlendirmeye tabi tutmadan ebeveynlerinden isteyebilmekte ve ebeveynler ihtiyaçları tam olarak karşılamayan alışveriş kararları verebilmektedir.

\section{YENI MEDYADA ÜRÜN YERLEŞTIRMENIN EBEVEYNLERIN SATIN ALMA EĞILIMIINE ETKİSİ: ÇOCUK VIDEOLARINA YÖNELIK KIRIKKALE İLINDE BİR ARAŞTIRMA}

\subsection{Araştırmanın Amacı ve Yöntemi}

$\mathrm{Bu}$ araştırmanın amacı, çocukların sosyal ağlarda izlediği videolarda yer alan ürünlere yönelik tüketicilerin (ebeveynlerin) algı, değerlendirme ve tutumlarını ve bunların videolara yerleştirilen ürünleri satın alma eğilimine etkisini incelemektir. Bu kapsamda, olumsuz etik algılama, videolardaki markalara yönelik tutumlar, videolardaki ürünleri satın alma eğilimleri, çocuğun satın alma talebi, reklam farkındalığı, markanın göze çarpma düzeyi, zihinsel işleme ve hatırlama değişkenleriyle ilgili birincil veriler toplanmıştır.

Araştırma değişkenlerinin ölçülmesinde konuyla ilgili bilimsel literatürdeki araştırmalarda kullanılan ölçüm araçlarından yararlanılmıştır. Soru formundaki maddelerin yanıt seçenekleri beşli Likert formundadır. (1. Kesinlikle Katılmıyorum, 2. Katılmiyorum, 3. Ne Katılıyorum Ne Katılmıyorum, 4. Katılıyorum, 5. Kesinlikle Katılıyorum). Bu kapsamda, işletmelerin sosyal ağlarda çocukların izlediği videolarda ürünlerin kullanılmasının sağlanmasına yönelik olumsuz etik algılamaları ölçmek üzere; Reidenbach ve Robin (1988), Reidenbach ve Robin (1990) ve Hudson ve Peloza'nın (2008) çalışmalarından yararlanılmıştır. Algılanan göze çarpma düzeyini belirlemek üzere Gupta ve Lord (1998) ve Chan vd.'nin (2016); işleme düzeyini belirlemek üzere Smith vd. (2008) ve Chan vd.'nin (2016); marka tutumlarını belirlemek üzere Matthes vd. (2007) ve Chan vd.'nin (2016); satın alma niyetini belirlemek üzere Smith vd. (2008), Lin ve Cho (2010) ve Chan vd.'nin (2016); hatırlama düzeyini belirlemek üzere Hudson ve Elliott'un (2013) ve reklam farkındalığını ölçmek üzere An vd.'nin (2014) çalışmalarından faydalanılmıştır. Bunların yanında, çocuğun sosyal medyada izlediği videodaki ürünü ebeveynden talep etme durumunu belirlemek üzere araştırma kapsamında üç maddeli ifade grubu oluşturulmuştur. Son olarak katılımcıların demografik özelliklerine yönelik sorular bulunmaktadır. Araştırma kapsamında, küçük yaş gruplarının (1-8 yaş) ebeveynlerine ulaşmanın zorluğu ve zaman-maliyet kısıtlarından dolayı kolayda örnekleme yöntemi ile 01.03.201931.03.2019 tarihleri arasında 200 ebeveynden birincil veri toplanmıştır. Elde edilen veriler S.P.S.S. istatistiksel paket veri analiz programıla analiz edilmiştir. 


\subsection{Araştırmanın Bulguları}

\subsubsection{Katılımcıların Demografik Özellikleri}

Araştırmaya katılanların cinsiyet dağılımları incelendiğinde; \% 56,5'inin kadın \%43,5'inin erkek olduğu görülmüştür. Yaş bakımından; katılımcıların \%31' inin 33 ve altı, \%52,5'inin 34-41 ve \%16,5'inin 42 ve üstü olduğu tespit edilmiştir. Gelir durumu bakımından incelendiğinde \%34,5'inin 0-2100 TL, \%30,5'inin 2101$3500 \mathrm{TL}$ ve \%35 inin $3501 \mathrm{TL}$ ve üstü olduğu anlaşılmıştır. Eğitim durumu bakımından; \%46,5'inin lise ve altı, \%53,5'inin yüksekokul ve üstü olduğu görülmüştür. Meslek durumu bakımından incelendiğinde; \%37,5'inin kamu çalışanı, \%28,5'inin özel sektör çalışanı ve \%33'ünün emekli veya çalışmadığı gözlemlenmiştir.

Tablo 1. Araştırmaya Katılanların Demografik Özellikleri

\begin{tabular}{|c|c|c|c|c|c|}
\hline \multicolumn{3}{|c|}{ CINSIIYET } & & & \\
\hline & $\begin{array}{c}\text { Miktar } \\
\text { n }\end{array}$ & $\begin{array}{c}\text { Geçerli Yüzde } \\
\% \\
\end{array}$ & & & \\
\hline KADIN & 113 & 56,5 & & & \\
\hline ERKEK & 87 & 43,5 & & & \\
\hline TOPLAM & 200 & 100,0 & & & \\
\hline \multicolumn{3}{|c|}{ YAŞ } & \multicolumn{3}{|c|}{ GELİR } \\
\hline & Miktar & Geçerli Yüzde & & Miktar & Geçerli Yüzde \\
\hline 33 ve altı & 62 & 31,0 & 0-2100 TL & 69 & 34,5 \\
\hline $34-41$ & 105 & 52,5 & 2101-3500 TL & 61 & 30,5 \\
\hline 42 ve Üstü & 33 & 16,5 & 3501 TL ve üstü & 70 & 35,0 \\
\hline Toplam & 200 & 100,0 & Toplam & 200 & 100,0 \\
\hline \multicolumn{3}{|c|}{ EĞİTiM } & \multicolumn{3}{|c|}{ MESLEK } \\
\hline & Miktar & Geçerli Yüzde & & Miktar & Geçerli Yüzde \\
\hline Lise ve altı & 93 & 46,5 & Kamu Çalışanı & 75 & 37,5 \\
\hline Yüksekokul & 56 & 28,0 & Özel Sektör & 57 & 28,5 \\
\hline Lisans ve üstü & 51 & 25,5 & İşsiz ve Emekli & 66 & 33,0 \\
\hline Toplam & 200 & 100,0 & Kayıp Veri & 2 & 1,0 \\
\hline & & & Toplam & 200 & 100,0 \\
\hline
\end{tabular}

Araştırmaya katılanların çocuklarının izlediği videolarda en fazla karşılaştığı ürün \%70 (140 kişi) oran ile oyuncaktır. Bunu \% 6 (12'şer kişi) ile yiyecek ve giyecek takip etmektedir. Bu sonuç, çocukların sosyal ağlarda izledikleri videolarda ebeveynlerin, çocukların ihtiyaçlarıyla ilgili bu ürünlerin olduğunun farkında olduğu anlaşılmaktadır. Ayrıca çocukların YouTube videolarında en fazla oyuncak ürünlerinin bulunduğu videoları izlemesinin yanında, oyuncak işletmelerinin bu videolarda ürün yerleştirme ile pazarlama mesajlarını ilettiği anlaşılmaktadır.

\subsubsection{Faktör ve Güvenirlik Analizi}

Araştırma soru formunun ana bileşenlerini anlamak amacıyla faktör analizi gerçekleştirilmiştir. Ayrıca araştırma soru formunun ve araştırma değişkenlerinin güvenirliğini belirlemek üzere Alfa katsayıları hesaplanmıştır (Genel alfa: 0,932). Araştırma soru formundaki maddelere yönelik gerçekleştirilen faktör analizi sonuçlarına göre, KMO katsayısı 0,873 olarak tespit edilmiş olup, bu değer faktör analizi uygulayabilmek için verilerin uygun olduğunu göstermektedir. Ayrıca Bartlett testine göre verilerdeki korelasyon yapısının da faktör analizi için uygun olduğu sonucuna varılmıştır. Analiz sonuçlarında ifadeler toplam varyansın \% 66'sını açıklayan 8 faktör altında toplanmıştır. Faktörler içerdiği soruların hazırlanma amacına uygun olarak dağılım göstermiş ve bu doğrultuda isimlendirilmiştir. 
İ. Bozacı - R. V. İşçan - İ. Gökdeniz 11/3 (2019) 1482-1492

Tablo 2. Faktör Analizi

\begin{tabular}{|c|c|}
\hline & Faktör Yükleri \\
\hline \multicolumn{2}{|c|}{ 1. Faktör: Olumsuz Etik Algılama } \\
\hline Çocuklara haksızliktır & 0,945 \\
\hline Geleneksel olarak kabul edilemez. & 0,945 \\
\hline Ahlaki olarak yanlıştır & 0,944 \\
\hline Kültürel olarak kabul edilemez. & 0,941 \\
\hline Çocuklar için adaletsizdir. & 0,938 \\
\hline Çocuklar için aldatıcıdır. & 0,935 \\
\hline \multicolumn{2}{|c|}{ Özdeğer: 11,416, Açılanan Varyans: 36,825, Toplam Açıklanan Varyans: 36,825, Alfa: 0,983, Ortalama: 3,8392 } \\
\hline \multicolumn{2}{|c|}{ 2. Faktör: Videolardaki Markalara Yönelik Tutumlar } \\
\hline Hoşuma gider & 0,875 \\
\hline Çekicidir. & 0,865 \\
\hline Caziptir. & 0,864 \\
\hline Çocuğumun gelişimi için yararlıdır. & 0,850 \\
\hline Güvenilirdir. & 0,815 \\
\hline \multicolumn{2}{|c|}{ Özdeğer:5,244, Açıklanan Varyans: 16,918, Toplam Açıklanan Varyans:53,743, } \\
\hline \multicolumn{2}{|c|}{ 3. Faktör: Videolardaki Ürünleri Satın Alma Eğilimi } \\
\hline İnternette araştırırım & 0,798 \\
\hline Mağazaya gittiğimde ararım & 0,796 \\
\hline Satın almak isterim & 0,780 \\
\hline İnternet üzerinden sipariş veririm. & 0,775 \\
\hline Satın alma tercihlerimi etkiler.(gıda vb. ) & 0,700 \\
\hline \multicolumn{2}{|c|}{ Özdeğer:3,408, Açıklanan Varyans:10,994, Toplam Açılanan Varyans:64,737 } \\
\hline \multicolumn{2}{|c|}{ 4. Faktör: Videolardaki Ürünleri Çocuğun Satın Alma Talebi } \\
\hline İzlediğinde satın almamı ister & 0,910 \\
\hline Mağazada gördüğünde satın almamı ister & 0,895 \\
\hline Kendisinin de sahip olmasını ister & 0,865 \\
\hline \multicolumn{2}{|c|}{ Özdeğer:2,124, Açılanan Varyans:6,851, Toplam Açılanan Varyans:71,588 } \\
\hline \multicolumn{2}{|c|}{ 5. Faktör: Reklam Farkındalı̆̆ı } \\
\hline Sadece bir tür reklamdır. & 0,900 \\
\hline Ticari amaçla gerçekleşir. & 0,899 \\
\hline İşletme satışlarını arttırmak için kullanılır. & 0,817 \\
\hline \multicolumn{2}{|c|}{ Özdeğer:1,767, Açılanan Varyans:5,701, Toplam Açılanan Varyans:77,289 } \\
\hline \multicolumn{2}{|c|}{ 6. Faktör: Göze Çarpma } \\
\hline Uzun süre kullanılır & 0,912 \\
\hline Ekranın önemli bir kısmını kaplar & 0,895 \\
\hline Kolayca fark edilir & 0,865 \\
\hline \multicolumn{2}{|c|}{ Özdeğer:1,332, Açıklanan Varyans:4,297, Toplam Açılanan Varyans:81,586 } \\
\hline \multicolumn{2}{|c|}{ 7. Faktör: Zihinsel İşleme } \\
\hline Dikkatimi veririm & 0,898 \\
\hline Neden orada göründüğünü düşünürüm. & 0,854 \\
\hline Çocuğumla ilişkilendiririm. & 0,845 \\
\hline \multicolumn{2}{|c|}{ Özdeğer:1,230, Açıklanan Varyans:3,967, Toplam Açıklanan Varyans:85,553 } \\
\hline \multicolumn{2}{|c|}{ 8. Faktör: Videolardaki Ürünleri Hatırlama } \\
\hline Ürünleri hatırlarım & 0,872 \\
\hline Markaları hatırlarım & 0,860 \\
\hline Ürünler aklımda kalıcı olarak yer eder & 0,764 \\
\hline
\end{tabular}

Araştırma değişkenlerinin ortalamaları incelendiğinde; katılımcıların olumsuz etik algılamalarla ilgili ifadelere katılma düzeyinde olduğu tespit edilmiştir (ortalama: 3,8392). Videolardaki markalara yönelik tutumlara yönelik ifadelere ise daha çok kararsızlık (ortalama: 3,4250) düzeyinde olduğu görülmüştür. Videolardaki ürünleri satın alma eğilimi ise katılma düzeyine daha yakındır (ortalama: 3,6080). Videolardaki ürünü çocuğun satın alma talebiyle ilgili ifadelere ise araştırmaya katılanlar katılma düzeyindedir (ortalama: 3,9500). Ayrıca katılımclar genel olarak videolardaki ürünlerin reklam olduğunun farkındadır (ortalama: 4,2967). Bunların yanında, videolardaki ürünlerin göz çarpma durumu yüksek olmayıp kararsızlık düzeyindedir (ortalama: 2,8508). Çocuğun izlediği videolardaki ürün markalarına dikkatini verme ve bunları düşünme düzeyi ise düşüktür (ortalama: 2,6967). Son olarak videolardaki ürünleri/markaları hatırlama düzeyi kararsızlık düzeyindedir (ortalama: 3,0467). 
İ. Bozacı - R. V. İşçan - İ. Gökdeniz 11/3 (2019) 1482-1492

Tablo 3. Ortalamaların İncelenmesi

\begin{tabular}{|l|c|c|}
\hline & Miktar & Ortalama \\
\hline Olumsuz etik algılama & 200 & 3,8392 \\
\hline Videolardaki markalara yönelik tutumlar & 200 & 3,4250 \\
\hline Videolardaki ürünleri satın alma eğilimi & 200 & 3,6080 \\
\hline Videolardaki ürünleri çocuğun satın alma talebi & 200 & 3,9500 \\
\hline Reklam farkındalığı & 200 & 4,2967 \\
\hline Göze çarpma & 200 & 2,8508 \\
\hline Zihinsel işleme & 200 & 2,6967 \\
\hline Videolardaki ürünleri-markaları hatırlama & 200 & 3,0467 \\
\hline
\end{tabular}

\subsubsection{Araştırma Değiş̧kenlerindeki Farklılıkların İncelenmesi}

Cinsiyete göre araştırma değişkenlerinin farklılaşma durumu incelendiğinde, sadece videolardaki ürünleri satın alma eğilimi ve videolardaki ürünleri çocuğun satın alma talebinin kadınlarda erkeklerden daha yüksek olduğu tespit edilmiştir. Diğer değişkenlerde anlamlı farklılığa rastlanmamıştır. Bu sonuçlar çocuğun sosyal ağlarda izlediği videolardaki ürünleri daha çok annelerin satın alma eğiliminde olduğu ve çocukların bunları daha çok annelerinden talep ettiği şeklinde yorumlanmaktadır.

Tablo 4. Cinsiyete değişkenine yönelik bağımsız örneklem t-testi sonuçları

\begin{tabular}{|l|l|c|c|c|}
\hline & Cinsiyet & Miktar & Ortalama & Sig. \\
\hline Videolardaki ürünleri satın alma eğilimi & Kadın & 113 & 3,8265 & \multirow{2}{*}{0,002} \\
\cline { 2 - 5 } & Erkek & 87 & 3,3241 & \\
\hline Videolardaki ürünleri çocuğun satın alma talebi & Kadın & 113 & 4,0767 & \multirow{2}{*}{$\mathbf{0 , 0 3 7}$} \\
\cline { 2 - 5 } & Erkek & 87 & 3,7854 & \\
\hline
\end{tabular}

Yaşa göre ortalamalar incelendiğinde, videolardaki ürünleri satın alma eğiliminin özellikle 42 ve üstü yaş grubunda belirgin şekilde daha düşük yaş gruplarından düşük olduğu görülmektedir. Diğer taraftan reklam farkındalığının 42 ve üstü yaş grubunda anlamlı düzeyde diğer yaş gruplarına göre düşük olduğu anlaşılmaktadır. Görece yaşlı gruptaki insanlar sosyal ağ videolarındaki ürünleri her ne kadar reklam olduğunu daha az düşünseler de, satın alma eğilimlerinin daha düşük olmasının; deneyimli tüketici olmaları, alışverişlerle ilgili iç tepkisellik ve dürtüselliklerinin daha az olmasıyla ilişkili olabileceği düşünülmektedir.

Tablo 5. Yaş değişkenine yönelik Anova sonuçları

\begin{tabular}{|l|l|c|c|c|}
\hline \multicolumn{2}{|c|}{} & Miktar & Ortalama & \\
\hline Videolardaki ürünleri satın alma eğilimi & 33 ve altı & 62 & 3,6806 & \multirow{3}{*}{$\mathbf{0 , 0 4 5}$} \\
\cline { 2 - 5 } & $34-41$ & 105 & 3,7010 & \\
\cline { 2 - 4 } & 42 ve Üstü & 33 & 3,1758 & \\
\hline Reklam farkındalığ & 33 ve altı & 62 & 4,4624 & \\
\cline { 2 - 4 } & $34-41$ & 105 & 4,3556 & \multirow{0}{*}{008} \\
\cline { 2 - 4 } & 42 ve Üstü & 33 & 3,7980 & \\
\hline
\end{tabular}

Gelire göre araştırma değişkenlerindeki farklılıklar incelendiğinde videolardaki markalara yönelik tutumların, videolardaki ürünleri satın alma eğiliminin ve reklam farkındalığının $2.100 \mathrm{TL}$ ve altı gelire sahip olanlarda, 3.501 TL ve üstü gelire sahip olanlara göre daha yüksek olduğu tespit edilmiştir. Ayrıca reklam farkındalığı $3.501 \mathrm{TL}$ ve üstü olan grupta diğer her iki gelir grubuna göre anlamlı düzeyde daha düşüktür. 
İ. Bozacı - R. V. İşçan - İ. Gökdeniz 11/3 (2019) 1482-1492

Tablo 6. Gelir değişkenine yönelik Anova sonuçları

\begin{tabular}{|c|c|c|c|c|}
\hline & & & & \\
\hline & & Miktar & Ortalama & Sig. \\
\hline \multirow{3}{*}{ Videolardaki markalara yönelik tutumlar } & $0-2100 \mathrm{TL}$ & 69 & 3,7072 & \multirow{3}{*}{0,018} \\
\hline & 2101-3500 TL & 61 & 3,3770 & \\
\hline & 3501 TL ve üstü & 70 & 3,1886 & \\
\hline \multirow{3}{*}{ Videolardaki ürünleri satın alma eğilimi } & $0-2100 \mathrm{TL}$ & 69 & 3,9101 & \multirow{3}{*}{0,015} \\
\hline & 2101-3500 TL & 61 & 3,5016 & \\
\hline & 3501 TL ve üstü & 70 & 3,4029 & \\
\hline \multirow{3}{*}{ Reklam farkındalığı } & 0-2100 TL & 69 & 4,5894 & \multirow{3}{*}{0,000} \\
\hline & 2101-3500 TL & 61 & 4,4699 & \\
\hline & 3501 TL ve üstü & 70 & 3,8571 & \\
\hline
\end{tabular}

\subsubsection{Videolardaki Ürünleri Satın Alma Eğilimine Yönelik Regresyon Analizi}

Araştırma değişkenlerinin videoların içerisinde gösterilen ürünleri satın alma eğilimine etkisini belirlemek üzere gerçekleştirilen regresyon analizine göre, araştırma modeli anlamlı bulunmuştur. Buna göre araştırma bağımsız değişkenleri, bağımlı değişkenin \% 57,4'ünü açıklamaktadır. Bağımsız değişkenler arasında videolardaki markalara yönelik tutumlar, çocuğun talebi, reklam farkındalığı ve videolardaki ürünleri ve markaları hatırlamanın, satın alma eğilimini etkilediği anlaşılmaktadır.

Tablo 7. Regresyon Analizi

\begin{tabular}{|l|c|c|c|}
\hline \multicolumn{2}{|l|}{ Bağımlı Değişken: Videolardaki Ürünleri Satın Alma Ĕ̆ilimi } & T & Sig. \\
\hline Sabit & Standart B &,- 544 &, 587 \\
\hline &, 055 & & \\
\hline Olumsuz etik algılama &, 512 & 1,081 &, 281 \\
\hline Videolardaki markalara yönelik tutumlar &, 162 & 7,902 &, $\mathbf{0 0 0}$ \\
\hline Videolardaki ürünleri çocuğun satın alma talebi &, 161 & 2,854 &, $\mathbf{0 0 5}$ \\
\hline Reklam farkındalı̆̆1 &,- 033 & 2,933 &, $\mathbf{0 0 4}$ \\
\hline Göze çarpma &, 016 &,- 621 &, 535 \\
\hline Zihinsel işleme &, 134 &, 290 &, 772 \\
\hline Videolardaki ürünleri-markaları hatırlama & R: 0,767 & $\mathrm{R}^{2}: 0,574$ &, $\mathbf{0 2 2}$ \\
\hline F: 25,905 & 0,000 \\
\hline
\end{tabular}

Sosyal medyada ürün yerleştirmenin etkilerini inceleyen araştırmalar genellikle yetişkinlerin izlediği veya dinlediği içeriklere yönelik olup, çocukların izlediği videolardaki ürün yerleştirmelerin etkilerine ilişkin araştırmalara rastlanmamaktadır. Araştırmada gerçekleştirilen analizler sonucunda; ebeveynlerin satın alma eğiliminde, videolardaki markalara yönelik tutum değişkenin belirgin şekilde diğer değişkenlere göre daha fazla etkili olduğu görülmektedir. Bu sonuç, geleneksel medyada ürün yerleştirmede televizyon showlarında kullanılan sevilen karakterlerin ürün yerleştirmenin etkisini artırdığını gösteren Patton (2014)'ün araştırmasıyla benzerlik gösterdiği söylenebilir. Ancak bu araştırmanın incelenen medya, izleyen kitle ve mesaj içeriği bakımından önemli farklılığı olduğu belirtilmelidir. Kısaca, ebeveynlerin çocuklarının izlediği videolardaki markaları olumlu karşılamasının, bu videolardaki ürünleri satın alma eğiliminde öncelikli bir faktör olduğu anlaşılmaktadır.

Ayrıca, videolardaki ürünleri çocuğun satın alma talebi, ürün yerleştirmenin ebeveynler üzerindeki etkisini artırmaktadır. Tüketici davranışları alanında çocuğun, satın alma kararlarının önemli bir etkileyicisi veya başlatıcısı olduğuna ilişkin genel görüşler (Kotler ve Armstrong, 1996: 159; Altunışık vd., 2006: 60), bu bulgularla örtüşmektedir. Ancak çocuğun satın almadaki etkisinin, 
sosyal ağlardaki videolarda karşılaştığı ürünlerden kaynaklanabileceği bu araştırma kapsamında ortaya konulmaktadir.

Bunların yanında videoların reklam olduğunun farkında olunmasının satın alma eğilimini pozitif yönde etkilemesi araştırma kapsamında beklenmeyen bir sonuçtur. Zira oyun reklamlarla ilgili gerçekleştirilen araştırmalar, reklam farkındalığının çocuğun reklama yönelik şüpheciliğini artırdığını ve satın alma eğilimini olumsuz etkilediğini göstermektedir (An vd., 2014; Vanwesenbeeck vd. 2017). Bu araştırma, küçük çocuklarına videoları izleme izni veren ebeveynlerle ilgilidir. Her ne kadar reklam farkındalığının reklamı izleme veya izletmekten kaçınmaya neden olması mümkün olsa da, bu araştırmada olduğu gibi çocuğun izlemesine izin verilmesi durumunda, reklam farkındalığının satın alma eğilimi üzerindeki negatif etkisinin, pozitif hale gelmesi ve reklamdaki ürünlerin satın alma eğiliminin artması söz konusudur. Bu durumun olası nedenlerinin ise; ebeveynlerin reklam farkındalığının kendilerinin izlediği değil çocuklarının izlediği ve izlemeye izin verdikleri videolarla ilgili olması, videoları izlemeye izin verme kararını destekleyici kararlarla kendileriyle çelişmemeye çalışmaları, bu mecradaki marka ve ürünleri çocukları için yararlı bulmaları gibi faktörlerle ilişkili olabileceği düşünülmektedir.

Araştırmada; olumsuz etik algılama, göze çarpma ve zihinsel işlemenin, ebeveynlerin çocuk videolarındaki ürünleri satın alma eğilimini etkilemediği anlaşılmaktadır. Bu sonucun, araştırmanın ebeveynlerin izlemeye izin verdikleri, büyük oranda çocukların izlediği ve zihinsel işleme tabi tuttuğu ürün yerleştirme mesajlarıyla ilgili olmasından kaynaklandiğ düşünülmektedir. Zira çocuklara izlemek için izin verilen ve çocukların büyük oranda izlediği pazarlama mesajlarının ebeveynlerin etik dışı algılamasının veya bu mesajlardaki ürün/markaların ebeveynlerin gözüne çarpmasının ve zihinsel işleme tabi tutmasının önemli olmadığı anlaşılmaktadır.

\section{SONUÇ}

Yeni medyada ürün yerleştirmenin bir türü olarak, sosyal ağlardaki çocuk videolarındaki ürün yerleştirmenin videolardaki ürünleri satın alma eğilimine etkisini incelemek üzere ebeveynlerden birincil veri toplanarak gerçekleştirilen bu araştırma sonuçlarına göre; videolardaki markalara yönelik tutum, çocuğun ebeveynden satın alma talebi, reklam farkındalığı ve videolardaki ürünleri/markaları hatırlama değişkenlerinin bu eğilimde önemli olduğu tespit edilmiştir. Bu değişkenler, satın alma eğiliminin \% 57'sini açıklamaktadır. Dolayısıyla sosyal ağ videolarında ürün yerleştirmenin, işletmelerin satışlarını etkileme potansiyeli olduğu anlaşılmaktadır.

Araştırmada, göze çarpma, zihinsel işleme ve olumsuz etik algılama değişkenlerinin etkili olmadığ1 tespit edilmiştir. Pazarlama literatüründe satın alma eğilimini etkilediği görülen bu değişkenlerin, öncelikle çocukların izlediği videolardaki ürünleri ebeveynlerin satın alma eğilimi bakımından etkisiz olduğu anlaşılmaktadır. Bunun öncelikli nedeninin, videolardaki markalara yönelik tutumlar ve çocuğun satın alma talebi başta olmak üzere, satın alma kararını etkileyen faktörlerin ön plana çıkması olduğu düşünülmektedir.

Yeni medyanın farklı alanlarında gerçekleştirilen ürün yerleştirmelerin etkilerine yönelik araştırmalar konunun anlaşılmasını kolaylaştıracaktır. Örneğin, sosyal ağlarda yetişkinlere yönelik eğitim, bilimsel veya eğlence videolarında ürün yerleştirmenin, tüketicinin satın alma eğilimini etkilemesi mümkündür. Bu durumda, videolardaki ürün yerleştirmeleri daha bilinçli değerlendirmelere tabi tutması söz konusu olan yetişkin tüketicilerin satın alma eğiliminde, göze çarpma, zihinsel işleme ve olumsuz etik algılama gibi değişkenlerin anlamlı etkilerinin olması mümkündür. 


\section{Kaynakça}

Altunışık, R., Özdemir, Ş. ve Torlak, Ö. (2006). Modern Pazarlama, Sakarya, Değişim.

An, S., Jin, H. S., ve Park, E. H. (2014). Children's advertising literacy for advergames: Perception of the game as advertising. Journal of Advertising, 43(1), 63-72.

Argan, M.; Velioğlu, M.N. ve Argan, M.T. (2007). Audience Attitudes Towards Product Placement in Movies: A Case from Turkey. Journal of American Academy of Business, Cambridge, 11(1), 161-168

Balasubramanian, S.K. (1994). Beyond advertising and publicity: hybrid messages and public policy issues. Journal of Advertising, 4, 29-46.

Brennan, I. (2008). Brand placement in novels: a test of the generation effect. International Journal of Advertising, 27(4), 459-509.

Brown, A., ve Moodie, C. (2009). The influence of tobacco marketing on adolescent smoking intentions via normative beliefs. Health Education Research, 24(4), 721-733.

Chan, F. F. Y., Lowe, B., ve Petrovici, D. (2016). Processing of product placements and brand persuasiveness. Marketing Intelligence \& Planning, 34(3), 355-375.

Chaney, I., Hosany, S., Wu, M. S. S., Chen, C. H. S., ve Nguyen, B. (2018). Size does matter: Effects of ingame advertising stimuli on brand recall and brand recognition. Computers in Human Behavior, 86, 311-318.

Chen, H., ve Deterding, A. (2013). College-aged young consumers' interpretations of product placement in social games. Young Consumers, 14(1), 41-51.

Chen, H., ve Haley, E. (2014). Product placement in social games: Consumer experiences in china. Journal of Advertising, 43(3), 286-295.

Cranwell, J., Murray, R., Lewis, S., Leonardi-Bee, J., Dockrell, M., ve Britton, J. (2015). Adolescents' exposure to tobacco and alcohol content in YouTube music videos. Addiction, 110(4), 703-711.

DeLorme, D. E., ve Reid, L. N. (1999). Moviegoers' experiences and interpretations of brands in films revisited. Journal of Advertising, 28(2), 71-95

Eagle, L., ve Dahl, S. (2018). Product placement in old and new media: examining the evidence for concern. Journal of Business Ethics, 147(3), 605-618.

Gillespie, B., Muehling, D. D., ve Kareklas, I. (2018). Fitting product placements: Affective fit and cognitive fit as determinants of consumer evaluations of placed brands. Journal of Business Research, 82, 90-102.

Gökhan, B. A. K., ve Eşidir, O. V. (2018). Sinemada Ürün Yerleştirme; Anadolu Kartalları Örneği. Elektronik Sosyal Bilimler Dergisi, 17(67), 1159-1166.

Gupta, P. B., Balasubramanian, S. K., ve Klassen, M. L. (2000). Viewers' evaluations of product placements in movies: Public policy issues and managerial implications. Journal of Current Issues and Research in Advertising, 22(2), 41-52.

Gupta, P.B. ve Lord, K.R. (1998). Product placement in movies: the effect of prominence and mode on audience recall. Journal of Current Issues and Research in Advertising, 20(1), 47-59.

Hackley, C., Szmigin, I. ve Tiwsakul R. (2005) Explicit, non-integrated product placement in British television programmes. International Journal of Advertising, 24(1), 95-111.

Hang, H., ve Auty, S. (2009). Video Games, Processing Fluency and Choice: Exploring Product Placement in New Media. Advances in Consumer Research, 36, 799.

Hudson, S., ve Elliott, C. (2013). Measuring the impact of product placement on children using digital brand integration. Journal of food products marketing, 19(3), 176-200.

Hudson, S., Hudson, D., ve Peloza, J. (2008). Meet the parents: A parents' perspective on product placement in children's films. Journal of Business Ethics, 80(2), 289-304.

Karrh, J. A., Frith, K. T., ve Callison, C. (2001). Audience attitudes towards brand (product) placement: Singapore and the United States. International Journal of Advertising Research, 20(1), 3-24.

Khan, A. U., Mahmood, A., Lodhi, R. N., ve Aftab, F. (2016). Influence of Product Placement on Consumer Behavior: The Mediating Roles of Consumer Recognition with Program Celebrity and Ethical 
İ. Bozacı - R. V. İşçan - İ. Gökdeniz 11/3 (2019) 1482-1492

Perceptions Towards Product Placement That Leads to Consumer Purchase Intention. Journal of Business Studies, 12(1), 168-184.

Kotler, Philip; Armstrong, Gary (1996), Principles of Marketing, Pearson Education, 7. Bask1, New Jersey.

La Ferle, C. ve Edwards, S.M. (2006). Product placement: how brands appear on television. Journal of Advertising, 35(4), 65-86.

Lee, M. ve Faber, R.J. (2007). Effects of product placement in online games on brand memory: a perspective of the limited-capacity model of attention. Journal of Advertising, 36(4), 75-90.

Lin, J. S., ve Cho, C. H. (2010). Antecedents and consequences of cross-media usage: A study of a TV program's official web site. Journal of Broadcasting \& Electronic Media, 54(2), 316-336.

Mackay, T., Ewing, M., Newton, F., ve Windisch, L. (2009). The effect of product placement in computer games on brand attitude and recall. International Journal of Advertising, 28(3), 423-438.

Matthes, J., Schemer, C. ve Wirth, W. (2007). More than meets the eye: investigating the hidden impact of brand placements in television magazines. International Journal of Advertising, 26(4), 477-503.

Mau, G., Silberer, G. ve Constien, C. (2008) Communicating brands playfully: effects of in-game advertising for familiar and unfamiliar brands. International Journal of Advertising, 27(5), 827-851.

McPherson, K. (2008). Product placement: facing yet another dark art. Teacher Librarian, 35(3), 66.

Patton, D. (2014). A Study of the Effect of Product Placement in Television Shows and Its Influence on Consumer Behavior, California Polytechnic State University, San Luis Obispo, The Faculty of the Communications Studies Department.

Pechmann, C. ve Shih, C. (1999). Smoking Scenes in Movies and Antismoking Advertisements Before Movies: Effects on Youth. Journal of Marketing, 63, 1-13

Reidenbach, R. E. ve Robin, D. P. (1988). Some Initial Steps Towards Improving the Measurement of Ethical Evaluations of Marketing Activities. Journal of Business Ethic,s 7(11), 871-879.

Reidenbach, R. E. ve Robin, D. P. (1990). Towards the Development of a Multidimensional Scale for Improving Evaluations of Business Ethics. Journal of Business Ethics, 9(8), 639-653.

Russell, C.A. ve Belch, M. (2005). A managerial investigation into the product placement industry. Journal of Advertising Research, 45(1), 73-92.

Schneider. L.P. ve Cornwell, T.B. (2005). Cashing in on crashes via brand placement in computer games: the effects of experience and flow on memory. International Journal of Advertising, 24(3), 321-343.

Smith, R.E., Chen, J. ve Yang, X. (2008), “The impact of advertising creativity on the hierarchy of effects, Journal of Advertising, 37(4), 47-61.

Smith, R.E., MacKenzie, S.B., Yang, X., Buchholz, L. ve Darley, W.K. (2007). Modeling the determinants and effects of creativity in advertising. Marketing Science, 26(6), 819-833.

Steortz, E.M. (1987). The cost efficiency and communication effects associated with brand name exposure within motion pictures. West Virginia Üniversitesi, Yayımlanmamış Yüksek Lisans Tezi, Morgantown.

Vanwesenbeeck, I., Ponnet, K., ve Walrave, M. (2017). Young adolescents' advertising literacy and purchase intention in social network games: Influence of perspective taking and need for cognition. Journal of Consumer Behaviour, 16(1), 23-33.

Waiguny, M. K., Nelson, M. R., ve Marko, B. (2013). How advergame content influences explicit and implicit brand attitudes: When violence spills over. Journal of Advertising, 42(2-3), 155-169.

Wenner, L. A. (2004). On the ethics of product placement in media entertainment. Journal of Promotion Management, 10(1-2), 101-132.

Williams, K., Petrosky, A., Hernandez, E., ve Page Jr, R. (2011). Product placement effectiveness: revisited and renewed. Journal of management and marketing research, 7, 1 . 